\title{
Climate and vegetation changes in the Northern Eurasia during the Younger Dryas
}

\section{Einleitung}

Vorliegender Beitrag zu Klima und Vegetation während der Jüngeren Dryas in Nordeurasien berichtet über die neuesten Forschungsergebnisse aus der ehemaligen UdSSR, welche anläßlich des internationalen Kongresses über die Wende Spät-/Postglazial in Moskau vom 16. bis 20. September 1992 am Geographischen Institut der Lomonossow-Universität mitgeteilt wurden. Die Autorinnen und Autoren dieses Artikels waren die Hauptorganisatoren dieser Tagung.

\section{Zusammenfassung}

Nachfolgend wird der rasche Klimawandel an der Wende Spät-/Postglazial dargelegt. Dieser Beitrag widmet sich der Rekonstruktion von Klima und Vegetation in Nordeurasien mit besonderer Berücksichtigung des Zeitabschnitts um 10000 Jahr B. P., d. h. der mittleren Jüngeren Dryas. Die Rekonstruktion der Vegetationsverhältnisse beruht auf detaillierten Paläoklimakarten mit numerischer Annäherung der Temperatur- und Niederschlagsverhältnisse. Die hier dargelegten Schlußfolgerungen werden durch verschiedene voneinander unabhängige Paläodaten bestätigt. C. A. Burga

\begin{abstract}
The climate development of the Late Glacial/Holocene transition is one of the most riveting problem of environmental change under short-term cooling. This paper is devoted to a special reconstruction of climate and vegetation in the Northern Eurasia with special reference to chronological level at 10,500 years b. p., i. e. just in the middle of the Younger Dryas. Reconstruction of vegetation was based on detailed palaeoclimate maps with numeric estimation of temperature and precipitation parameters. Concluding results were affirmed by independent palaeodata.
\end{abstract}

\section{Introduction}

The reconstruction of natural zonality and its dynamics in the past provides the adequate possibilities to estimate the modern and future environmental condition. Studies of the time interval during the climate transit from the Late Glacial to the Holocene are of great interest because this period includes a sequence of short-term ( 100 years span) cooling, marked by the geochronological and palaeogeographical data on the whole territory of the Northern Hemisphere. The majority of researchers supposes them to be the natural boundary between Pleis- tocene and Holocene (KHOTINSKY 1977, KOTLYAKOV et al. 1989). It was global cooling that lasted ca. 500 years and was accompanied by large advances of inlandices and mountain glaciers between 10,800 and 10,300 years b. p. The influx of periglacial vegetation gave occasion to call it the Younger Dryas (IVERSEN 1954, 1967). This term became gradually world-wide known especially due to its identification with the termination of the Pleistocene. General information on the environment during the Late Glacial for the former USSR is represented essentially in all monographs, regional overviews and articles devoted to the palaeogeography and geology of Pleistocene and Holocene (AVENARIUS et al. 1978, VELICHKO 1984, VELICHKO \& FRENZEL 1992, MARKOV et al. 1967, KIND 1974). It is untenable to give their full overview in this paper. We should mark only the lack of detailed palaeoclimate maps with numeric estimation of climatic parameters for the investigated area.

\section{Methods}

The construction of the palaeogeographical maps for vast areas with significant variety of natural conditions needs a quite specific methodological approach. Mathematical models are supposed to be the most functional in palaeoreconstruction (SOLOMON et al. 1980, KUTZBACH et al. 1986, PRENTICE et al. 1989). The simple palaeoclimatic model (GEOMAP) has been worked out to simulate the prehistoric climatic condition (LIBERMAN et al. 1985, GROSSVALD et al. 1985, MURATOVA et al. 1987, 1988). It is based on nonlinear interpolation of sparse determination of temperature and precipitation parameters for specified time intervals in some points, derived from palaeorecord. We have used $\mathrm{C}^{14}$ dated pollen data for the land surface and microfauna for the upper layer of the ocean. As an output GEOMAP has produced the following climatic parameters: average July and January temperatures and mean annual precipitation.

Marina V. Muratova, Department of Geography, Moscow State University, 119899 Moscow, Russia;

Leonid R. Serebryanny, Institute of Geography, Russian Academy of Science, 109017 Moscow, Russia; Olga V. Denissenko, Sergey V. Kiselev, Department of Geography, Moscow State University, 119899 Moscow, Russia. 
The simulated values were compared with the results of independent analysis of fossil beetle faunas synchronous with the Younger Dryas time. Nowadays the significance of beetle fauna for the palaeogeographical reconstruction, for the determination of the landscape type and for the specification of climatic parameters has been well proved (KISELEV et al. 1984). Climatic changes are completely reflected in quantitative and qualitative characteristics of the fossil beetle fauna represented in palaeontological annals. Palaeoclimatic reconstructions were used as a data base for the vegetation reconstructions for the former USSR during the Younger Dryas. For this purpose we have used data showing the correlation between vegetation zone position and climatic patterns distribution. They were derived from the statistical processing of 280 sites on modern vegetation and climate map for the investigated area.

\section{Results}

\section{General climatic characteristic during the Younger Dryas}

In most parts of the former USSR the Younger Dryas was marked by the cooling and decrease of precipitation in comparison with the present data. The analysis of compiled GEOMAP maps (fig. 1) shows that the cooling was not significant within high latitude areas of Eurasia (not more than $1{ }^{\circ} \mathrm{C}$ ), and on the coast of the Arctic Ocean the average July temperatures were even a little bit higher than the modern ones.
The results of the independent analysis of the beetle fauna of the Northern Eurasia synchronous with the Younger Dryas cooling give evidence of stable temperature regime (KISELEV 1981, 1988, KISELEV et al. 1984, KISELEV et al. 1987). According to the data from Kolyma and Indigirka river basins the climate similar to the modern one has established 11,000-10,000 years b.p. (average July temperatures were $12^{\circ}-13^{\circ} \mathrm{C}$ and mean annual precipitation 150-200 mm). In the areas of the modern Arctic coast of the West Chukotka average July temperatures stabilized on the $12^{\circ} \mathrm{C}$ level and precipitation was equal to $200 \mathrm{~mm}$. For the mountains of the lower Kolyma river basin the average July temperatures were $10^{\circ} \mathrm{C}-12{ }^{\circ} \mathrm{C}$ while mean annual precipitation $200-300 \mathrm{~mm}$. These parameters (mostly temperature) were lower than the modern ones. According to the fossil beetle fauna analysis the climate of the Western Siberia coastland (Gydan peninsula) and the European North-East (Yugorsky peninsula) during the Younger Dryas was similar to the modern.

Data obtained from the study of the fossil soils in the areas of the lower reaches of $\mathrm{Ob}$ and Yenisey rivers, on the Yamal peninsula, Ayon island in Chaunskaya guba, on Svalbard and Novaya Zemlya archipelagoes proved the stability of the temperature regime on the far North of the former USSR. The soil formation started in this region 11,000 years b.p. and finished near 7,000 years b. p. (EVSEEV et al. 1986). This period is characterized by soils with well developed profiles. Their formation took place during climate conditions close to modern ones.

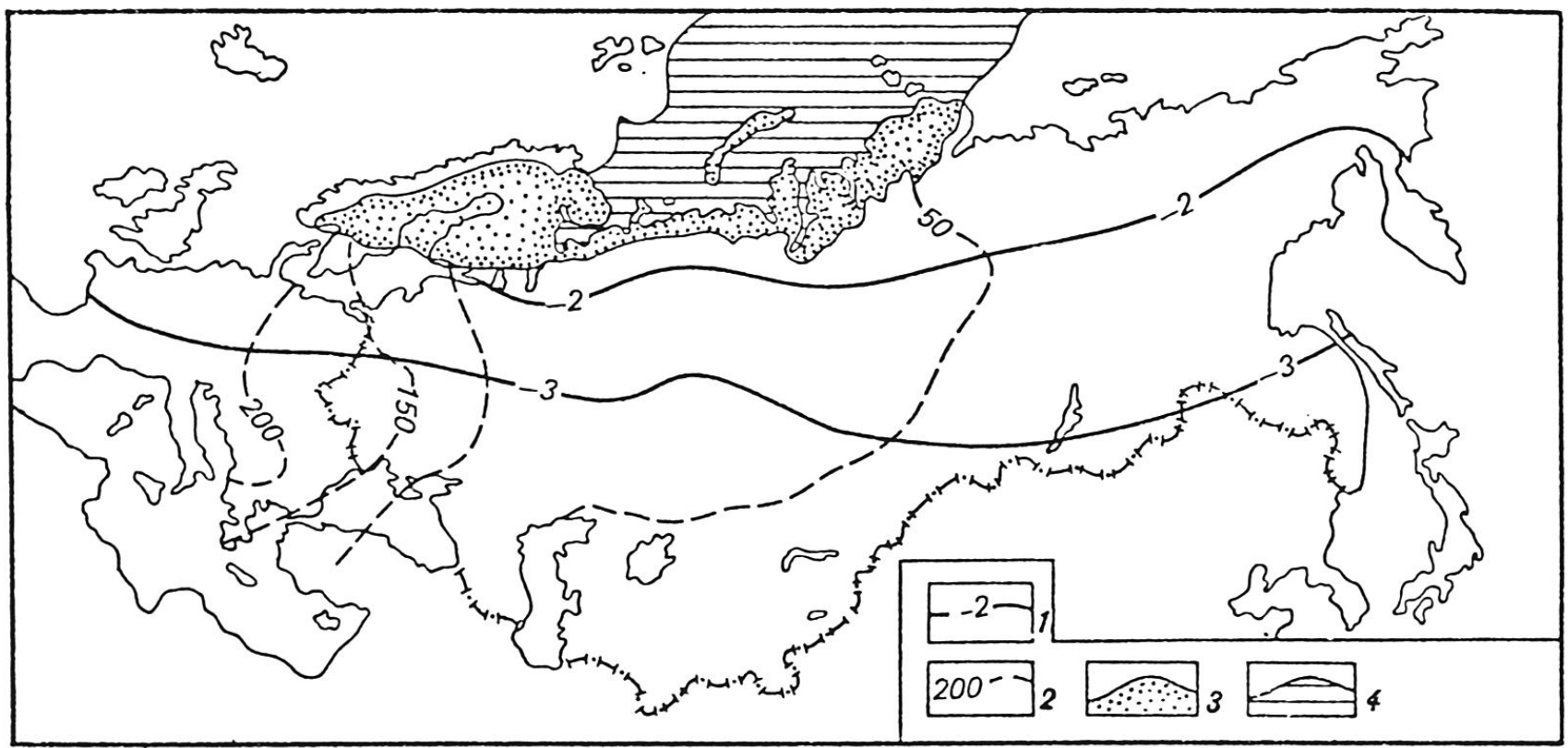

Fig. 1 Map of temperature and precipitation deviations in the Northern Eurasia for the Younger Dryas

1. Average July temperature deviations

2. Mean annual precipitation deviations

3. Glacial sheets

4. Glaciers in the ocean 
From GEOMAP simulations it is evident that July temperatures increased gradually southward to the Polar Circle. On the $50 \mathrm{~N}$ temperature anomalies (the difference between palaeo and modern temperatures) reached $3{ }^{\circ} \mathrm{C}$. Within these latitudes negative deviations most abruptly were expressed on the Pacific coast. In the Kamchatka peninsula the difference was equal to $2{ }^{\circ} \mathrm{C}$ but in $\mathrm{Chu}$ kotka peninsula average July temperatures were equal to the modern ones. The maximum cooling $\left(3^{\circ}-4^{\circ} \mathrm{C}\right)$ took place in the European sector, simultaneously with greater meridional atmospheric and oceanic flow, severe snowfalls and flux of icebergs in the North Atlantic (MILLER \& KAUFMAN 1991). GEOMAP simulation shows that the most significant dryness and cooling were expressed in the Mediterranean on the $30 \mathrm{~N}$. The distribution of negative temperature anomalies showed that they were subjected to the latitude zonality, while the distribution of negative precipitation anomalies was rather longitudinal. During the Younger Dryas the whole territory of the former USSR and Western Europe had significantly lesser precipitation than nowadays. The minimum difference was observed on the extreme of the North-Eastern part of the continent, the maximum in the regions exposed to the North Atlantic margin. Within the continental regions of East and Middle Siberia this difference didn't exceed $50 \mathrm{~mm}$ per year, while in the West Siberia region it was about $100 \mathrm{~mm}$. In Middle Asia and Altai negative anomalies were negligible (about $50 \mathrm{~mm}$ per year), but rather discernible as it is evident by analytical information (SEREBRYANNY et al. 1980; MURZAEVA et al. 1984, BUTVILOVSKY et al. 1992). Probably the zone of maximum humidity was shifted to high mountains, and middle and low mountains had drier environments. Westward from the Urals the differences in precipitation increased to $150 \mathrm{~mm}$ and on the Atlantic coast the difference has become more noticable and reached $400 \mathrm{~mm}$. Hence the sharp deviation in the climate regime of the Younger Dryas according to the simulations took place within the middle latitudes adjacent to the Atlantic coast, whereas in the continental region essential climate change was not found.

The attachment of maximum cooling to the North Atlantic coastlands led us to the decision to analyse the temperatures of the Atlantic surface water during the Younger Dryas. The map of the model is based on 19 values of palaeotemperatures, determined by Prof. M.K. BARASH. These values were derived from marine micropalaeontological data. According to the GEOMAP simulating temperature deviations it is clear that the area with maximum cooling lied in the Eastern part of the North Atlantic between $35 \mathrm{~N}$ and $45 \mathrm{~N}$ and the adjacent part of Mediterranean sea (fig. 2). On the Iberian Peninsula the negative temperature deviations were $8^{\circ} \mathrm{C}$, and within the Mediterranean, especially in its Western and Central parts, the negative anomalies reached $9{ }^{\circ} \mathrm{C}$. These conclusion were proved in some features by reconstruction of RUDDIMAN and McINTYRE (1981). According to their opinion, the polar front on ocean shifted rapidly from the Island - where it had been situated during the

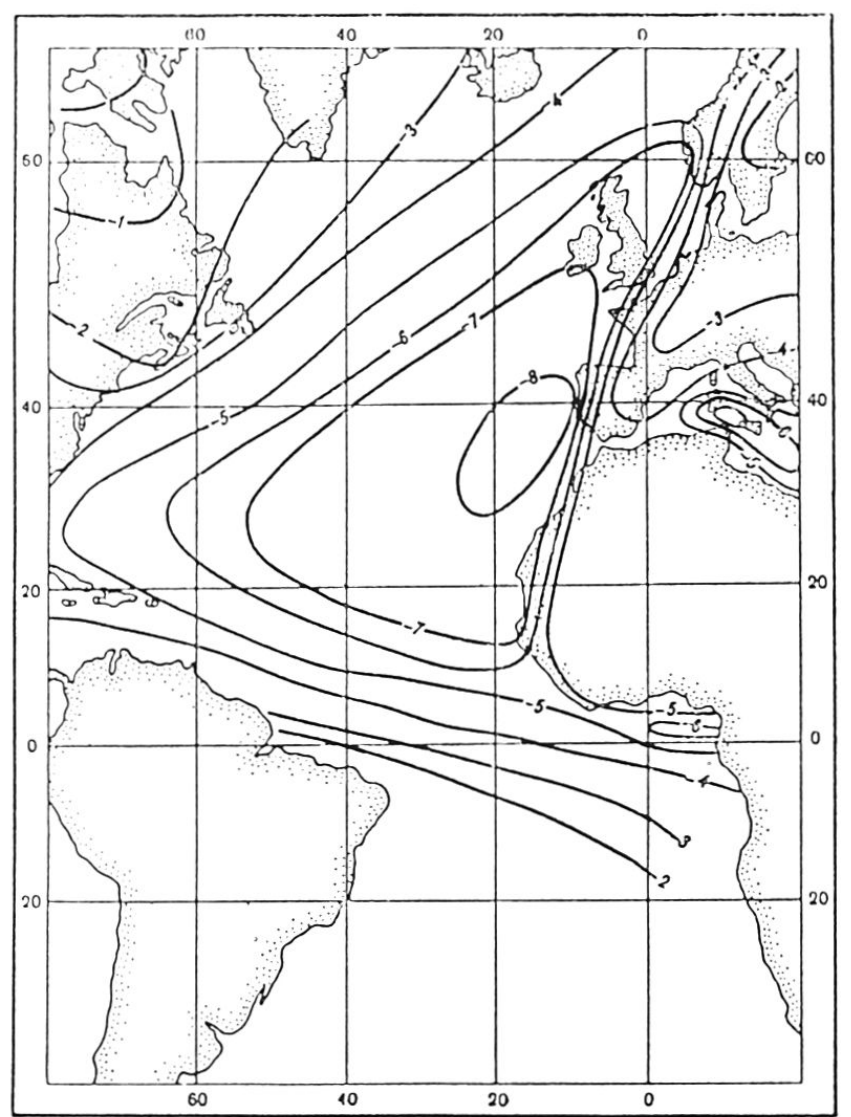

Fig. 2 Map of temperature deviations of the North Atlantic for the Younger Dryas.

proceeding Alleröd warm phase - towards the Iberian Peninsula latitudes during the time interval 10,000 10,500 years b. p., whereas its position in the Western Atlantic, near American coast, didn't change.

\section{Major trends in vegetation history during the Younger Dryas}

During the Younger Dryas the vegetation zones in Northern Eurasia had a rather distinctive pattern (Fig. 3). Since the cooling practically didn't touch the high latitudes areas of the Northern Hemisphere, the borders and the areas of Arctic and typical tundra zone analogues were approximately similar to the present ones. This fact is supported by the vast palaeobotanical data (MURATOVA 1973, KHOTINSKY 1977). Several data refer to typical tundra existence in the Ust-Port region (70 N, $83 \mathrm{E}$ ) (KIND 1974). The southward penetration of tundra in NorthEastern Europe is also supported by palynological data (NIKIPHOROVA 1982). The areas of mountain tundra didn't increase to great extent while forest tundra significantly expanded southward to the areas which nowadays are occupied by Northern taiga. This phenomena was marked more distinctly within the limits of the Russian Plain (KHOTINSKY 1977), KAPLINA et al. 1982).

Climatic simulations are well proved by fossil beetle fauna. It included typical species for the present Hypo- 


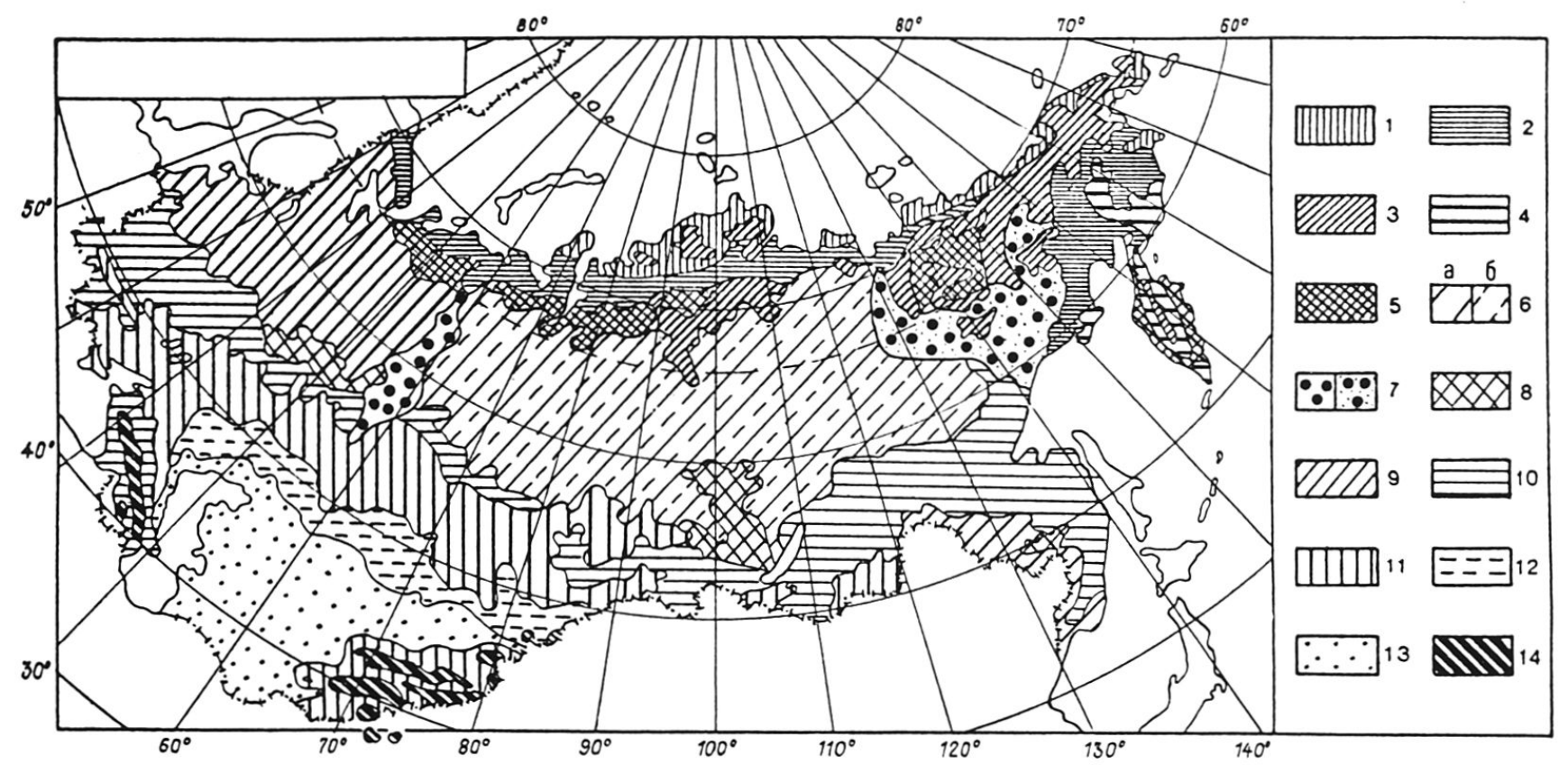

Fig. 3 Vegetation map of the Northern Eurasia for the Younger Dryas, 10,500 years b. p.
1. Arctic tundra
7. Mountain taiga open woodland
2. Typical tundra
3. Mountain tundra
4. Shrub tundra with Pinus Pumila
5. Forest tundra
6. Taiga open woodland:
a) Picea
b) Larix
8. Southern taiga and open woodland
9. Mixed forest
10. Forest steppe
11. Steppe
12. Semidesert
13. Desert
14. Evergreen mountain forest

arctic (ground beetles Blethisa catenaria brown, Curtonotus alpinus Payk, Pterostichus species of Cryobius and Europeris subgenus, leef beetles Chyosolina cavigera Sahlb., Ch. subsulcata Mnnh., weevil Phytonomus ornatus cap., Sitona ovipennis borealis Korot., Lepurus nordenskjoeldi Faust etc.) as well as species which are not typical or completely absent in this region coexisting on the vast East Siberia coastal plains until the end of the Pleistocene. The last group was represented by the various forms, consisting of "steppe" and partially "meadow steppe" beetles (the weevil species Stephanocleorus and Coniocleonus, Phyllobius crassus Motsch., the ground beetles Cymindis arcticus Kryzh et Em., Harpalus obtusus amputatoides Mlynar, Harp. vittatus kiselevi Kataev, leaf beetle Chrysolina perforata Gebl. and some others). A particular place in the beetle fauna composition belonged to the peculiar pill-beetle Morychus viridis Kuzm. et Korot. (KUZ. MINA et al. 1987). The beetle Morychus viridis was found almost everywhere in the chionophobous xerophytic communities with the dominance of the sedges Carex argunensis and moss Polytrichum piliformis and codominance of Carex rupestris, C. obstusata and Dryas octopetala (BERMAN 1990 a, b). The progressive decrease of this beetle in modern environment is well correlated with the increase of the vegetation cover, except the sedges above mentioned. Nowadays it is impossible to verify a signifi- cant accumulation of beetle Morychus viridis which could be compared with the quantities of this beetle during the Pleistocene. As it is shown in the Table 1, almost everywhere the significant role of xerophytic tundra biotop species (maximum 40\%, minimum 20\%) was marked. Habitats of the hydro-mesomorphic biotops, especially the ground-beetles, were not so typical. The shares of the representatives of the steppe and meadow steppe were equally corresponding to $5-10 \%$ and $10-15 \%$ in average. The species connected mainly with the willows (weevil Lepurus and Phunchaenus) played a rather negligible role. The most significant elements of the palaeolandscapes were those with the considerable drainage and with the patches of the vegetation cover. The plant communities with the dominance of Arcticus Alpinus species, the pillows of Dryas combined with the different species of Saxifraga, Polygonum and grasses Poa, which are spread nowadays, could be considered as their modern analogue. The second place was ocuppied by the different variants of biotops of steppe meadows and steppe spots dominated by Artemisia. The plant community with the dominance of Carex argunensis as a habitat of Morychus viridis were also widely spread in this area. The distribution of the analogues of the moss and Eriophorum vaginatum tundra and mesophytic shrubs or shrubs associations (with the participation of birch, willow shrubs and even willow ar- 
SAMPLE SUM ECOLOGICAL GROUPS

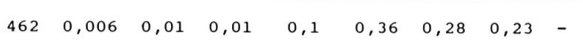

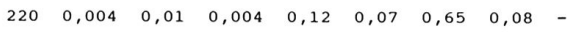
$46 \quad-0,04 \quad-\quad 0,37 \quad 0,19 \quad 0,28 \quad 0,11 \quad-$

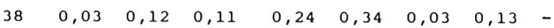
50 - $\quad 0,06 \quad 0,02 \quad 0,22 \quad 0,04 \quad 0,620,02 \quad-$ $87 \quad-\quad 0,08 \quad 0,02 \quad 0,25 \quad 0,19 \quad 0,24 \quad 0,22 \quad-$ 37 - $\quad 0,31 \quad 0,220,220,11 \quad-\quad 0,110,03$ $33 \quad-\quad-\quad 0,540,340,03 \quad-\quad 0,030,06$ $\begin{array}{lllllllllllll}33 & 0,03 & 0,06 & 0,73 & 0,15 & - & - & - & 0,03\end{array}$

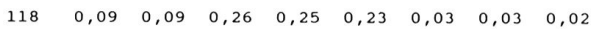

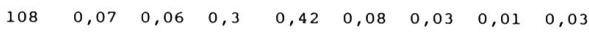

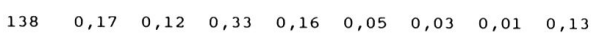
$\begin{array}{lllllllll}81 & 0,01 & 0,04 & 0,37 & 0,29 & 0,2 & 0,01 & - & 0,06\end{array}$

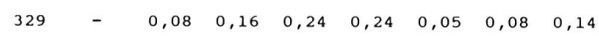
$\begin{array}{lllllllll}366 & 0,03 & 0,09 & 0,22 & 0,17 & 0,26 & 0,06 & 0,09 & 0,03\end{array}$ $\begin{array}{llllllllll}57 & 0,03 & 0,05 & 0,16 & 0,33 & 0,14 & 0,18 & 0,11 & -\end{array}$

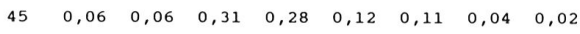

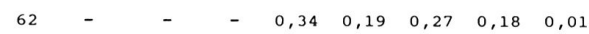
77 - $\quad$ - $\quad 0,02 \quad 0,18 \quad 0,56 \quad 0,11 \quad 0,11 \quad-$ $\begin{array}{lllllllll}67 & 0,03 & 0,04 & 0,43 & 0,1 & 0,12 & 0,01 & 0,01 & 0,25\end{array}$ $\begin{array}{lllllllll}44 & 0,07 \quad & - & 0,38 & 0,34 & - & 0,02 & 0,06 & 0,11\end{array}$ $96 \quad-\quad \begin{array}{llllllllll}0,19 & 0,19 & 0,08 & 0,36 & - & 0,16 & -\end{array}$ $63-\quad-0,220,250,14 \quad-\quad 0,080,04$ $27 \quad$ - $\quad-\quad \begin{array}{llllllll}0,22 & 0,19 & 0,37 & 0,15 & 0,07 & \text { - }\end{array}$ $\begin{array}{lllllllll}40 & 0,05 & - & 0,15 & 0,25 & 0,3 & 0,07 & 0,15 & 0,02\end{array}$ $\begin{array}{llllllllll}67 & 0,01 & 0,04 & 0,48 & 0,3 & 0,07 & - & 0,03 & 0,06\end{array}$

$\begin{array}{lccccccccc}29 & 60 & 0,08 & 0,06 & 0,36 & 0,21 & 0,16 & 0,01 & - & 0,05 \\ 30 & 57 & - & 0,03 & 0,05 & 0,21 & 0,52 & 0,03 & 0,09 & 0,05 \\ 31 & 20 & - & 0,05 & 0,55 & 0,2 & - & 0,05 & - & 0,15 \\ 32 & 19 & 0,16 & - & 0,31 & 0,21 & - & 0,11 & - & 0,21 \\ 33 & 64 & 0,06 & 0,19 & 0,41 & 0,17 & 0,03 & 0,05 & - & 0,09 \\ 34 & 20 & 0,1 & - & 0,63 & 0,2 & - & - & - & 0,05 \\ 35 & 38 & 0,31 & 0,05 & 0,34 & 0,18 & 0,02 & 0,02 & - & 0,03 \\ 36 & 56 & 0,04 & 0,16 & 0,44 & 0,23 & - & 0,11 & - & 0,02 \\ 37 & 79 & 0,06 & 0,15 & 0,55 & 0,13 & - & 0,01 & 0,06 & 0,07 \\ 38 & 42 & 0,09 & 0,12 & 0,55 & 0,1 & - & 0,09 & - & 0,05\end{array}$

Ecological groups index: A - aquatic; $R$ - riparian, flood plain; H-M - hydro-mesic Tundra; X - xeric Tundra; Dr Carex-Dryas type; Gr - grassland-meadow type; $\mathrm{s}$ - Steppe type; Tr - shrubs-trees vegetation.

Sample locality : $1,2-168^{\circ} 43 \mathrm{~N}, 157^{\circ} 25^{\prime} \mathrm{E} ; 3-69^{\circ} 4^{\prime} \mathrm{N}$ $158^{\circ} 10^{\prime} \mathrm{E} ; 4-69^{\circ} 30^{\prime} \mathrm{N}, 161^{\circ} 48^{\prime} \mathrm{E} ; 5-69^{\circ} 48^{\prime} \mathrm{N}, 159^{\circ} 20^{\prime} \mathrm{E} ; 6-$ $69^{\circ} 50^{\prime} \mathrm{N}, 159^{\circ} 25^{\prime} \mathrm{E} ; 7-61^{\circ} \mathrm{N}, 151^{\circ} 25^{\prime} \mathrm{E} ; 8,9-63^{\circ} \mathrm{N}, 148^{\circ} \mathrm{E} ; 10-$ $12-69^{\circ} 35^{\prime} \mathrm{N}, 166^{\circ} 40^{\prime} \mathrm{E} ; 13-69^{\circ} 35^{\prime} \mathrm{N}, 166^{\circ} 35^{\prime} \mathrm{E}$; $14-19-69^{\circ} 30^{\prime} \mathrm{N}, 169^{\circ} \mathrm{E} ; 20-73^{\circ} 50^{\prime} \mathrm{N}, 143^{\circ} 10^{\prime} \mathrm{E} ; 21-$ $76^{\circ} 10^{\prime} \mathrm{N}, 144^{\circ} 10^{\prime} \mathrm{E} ; 22-71^{\circ} 42^{\prime} \mathrm{N}, 148^{\circ} 10^{\prime} \mathrm{E} ; 23-72^{\circ} 30^{\prime} \mathrm{N}$, $141^{\circ} \mathrm{E} ; 24-70^{\circ} 43^{\prime} \mathrm{N}, 149^{\circ} 28^{\prime} \mathrm{E} ; 25,26-70^{\circ} 31^{\prime} \mathrm{N}, 149^{\circ} 43^{\prime} \mathrm{E} ; 27-$ $70^{\circ} 39^{\prime} \mathrm{N}, 150^{\circ} 30^{\prime} \mathrm{E} ; 28,29-69^{\circ} 10^{\prime} \mathrm{N}, 147^{\circ} 30^{\prime} \mathrm{E}, 30-69^{\circ} 48^{\prime} \mathrm{N}$ $146^{\circ} 20^{\circ} \mathrm{E} ; 31-72^{\circ} \mathrm{N}, 123^{\circ} \mathrm{E} ; 32-72^{\circ} 30^{\prime} \mathrm{N}, 115^{\circ} \mathrm{E} ; 33-71^{\circ} 50^{\prime} \mathrm{N}$, $83^{\circ} 30^{\circ} \mathrm{E}, 34-72^{\circ} \mathrm{N}, 74^{\circ} \mathrm{E} ; 35-68^{\circ} \mathrm{N}, 70^{\circ} \mathrm{E} ; 36-38-68^{\circ} 45^{\circ} \mathrm{N}$, $65^{\circ} \mathrm{E}$. 
boreal) was limited by the relief depressions including valleys and by the coasts of the natural reservoirs. The rate of these communities increased in the North (including the dry shelf) and in the West of the area. This demonstrates the zonal and sector dissimilarity of the vegetation cover. In comparison with the continental lowlands average July temperatures decreased to $10{ }^{\circ} \mathrm{C}$ and precipitation increased towards the modern level. The beetle fauna of the coastal plane from the lower reaches of river Lena was characterized by approximate equal participation of the xeromorphic and hydro/mesomorphics forms of tundra communities. The rate of meadow beetles significantly decreased, and the steppe beetles were completely absent. Note that the last group was marked in big variety of the forms to the East of the Verkhoyanskiy ridge. Pill-beetle Morychus viridis was defaced not very often and as a rule solitary, whereas the beetles trophically connected with arboreal and shrubby willow (Rhynchaenus arcticus, Dorytomus and Lepyrus) were abundant. In general tundra type landscapes prevailed in the vast coastlands of the Arctic Ocean from the mouth of river Lena to the Taimyr Peninsula. These landscapes differed from the present tundra by larger participation of the grass/herbs and shrub/herbs communities. Beetle fauna on the Gydan peninsula indicated the stable climate conditions and relatively uniform landscapes throughout the most part of the Late Quaternary. The dominance of the tundra beetle communities assembled in hydro-mesomorphic ecological group was typical. The presence of several beetle forms typical for meadow biotops of the West Siberian boreal zone (f. g. weevil Otiorrhynchus politus Gyll., Ot. arcticus F.) is also worthy of notice. The peculiarities of the beetle fauna composition, especially their ecological demands suggest a decrease of precipitation combined with a synchronous increase of average July temperature to $11^{\circ} \mathrm{C}-12^{\circ} \mathrm{C}$.

The area of Northern Taiga was twice bigger than nowadays. It spread out on the region of present Middle and Southern Taiga and partly even of the mixed deciduous forests. During the Younger Dryas, the Northern Taiga can be identified as an open woodland because of lesser precipitation especially within the European Plain. The vestiges of climatic aridity were of widespread occurrence according to the palaeovegetation records. The pollen of tundra and cool steppe primitive plant aggregation combined with the arboreal pollen was rather typical for forest zone spectra. The set of plant communities seem to be different from the modern one.

KHOTINSKY (1977) was the first who demonstrated on the base of palaeobotanic studies the suppressing of forest vegetation and development of steppe and often tundra communities on the whole investigated area. The declined forest communities were replaced by open woodland of pine and birch, unusual for these regions. The vegetation of these forests with the dominance of the steppe xerophytic and representatives of the tundra flora was identified by FRENZEL (1968) as "tundra-steppe". The idea of the extensive distribution of peculiar "cool" landscapes which didn't have any modern analogues was confirmed by other palaeobotanic studies. KARAULOVA (1991) supports the idea of the presence of larch-birch open woodland in Siberia $(61 \mathrm{~N}, 70 \mathrm{E})$ and birch-pine open woodland in the Far East $(43 \mathrm{~N}, 132 \mathrm{E})$. The distribution of the wormwood-goosefoot communities with the representatives of forest and tundra zones was marked in the Polar Urals (suRova et al. 1975). The periglacial pine and birch forest steppe existed in Eastern Europe. Such landscapes with pine parklands and prevailing wormwood/grass communities were described at the slopes of glint near St. Petersburg at the end of the Younger Dryas (SEREBRYANNy 1978). The wormwood xerophytic communities penetrated to Southern Taiga in the West Siberia at the end of the Late Glacial (PIAVCHENKO 1968). The Middle Taiga was spread within limited areas near the Urals mountains, nowadays occupied by mixed forest. At 10,500 years b. p. the Southern Taiga practically disappeared, only few spots seemed to be present in the Fast East. In general, both areas of Middle and Southern Taiga were by seven times smaller than the modern zones.

The role of the forest steppe transition zone increased significantly during the cooling phase because of its Northward expansion. Under drier and colder climate, the forest steppe occupied the area of present broadleaved forests in the West and larch forests in the East of the former USSR (VIPPER 1975). The significant shift of the steppe border Northward was caused by increasing aridity. During the Younger Dryas there were few broadleaved forests now distributed on the vast areas as important phytomass accumulators.

Nevertheless, in the last years we have some indications about the preservation of forest stands in the Southern Middle Russian heights, Eastern Crimea, Lower Volga region and even Central Kazakhstan (T.A. SEREBRYAN. NAYA, N.S. BOLIKHOVSKAYA, P.E. TARASOV, verbal communication). These stands are treated as the remnants of forest zone which shifted southwards during the maximum of Late Pleistocene glaciation. As this information is quite new, we have not succeded to put it into the model, and the Southern fringes of our maps probably will be considerably refined in the nearest future.

\section{Discussions}

The problem of instability of the climatic system "ocean atmosphere - cryosphere" is very intricate. This complicated self-regulated system maintains in the condition close to the unstable equilibrium. According to regularities of the nature development in certain time interval when one of the components changes its structure or when the unstable equilibrium reaches its critical limit the whole system disrupts. This phenomena creates short-term climatic oscillations: warm periods alternate the cool ones. The extensive palaeoclimate information including numeric estimations of temperature suggest 
that the time scale of the climate change during the transition from glacial to interglacial period is much more complicated than the classical geochronological scales (MILANKOVICH 1938, EMILIANI 1966, EMILIANI et al. 1975). Late Glacial and Holocene provide the unique opportunity of rather detailed study of climate change. In this climatic stratigraphic scale one can underline the events of two ranks: major glacial/interglacial, which are well recognized in the Northern Hemisphere and series of short-term climate oscillations of different intensity as well as within every major interval. This oscillations coincided with the final glacial phases and have distinct tendency towards damping. The time sequence which took place during the glacial contraction is well known. Warm and cool periods with $6{ }^{\circ} \mathrm{C}$ average global temperature amplitude were marked at the end of deglaciation within 2,000 years. The last of them was the cooling at 10,800-10,300 years b. p. (Younger Dryas).

During cool periods the temperature decrease reached $5^{\circ}-6^{\circ} \mathrm{C}$ within one century contrary to the present oscillation, which doesn't exceed $1{ }^{\circ} \mathrm{C}$ (BUDYKO 1986). The main reason of their manifestation was the regular disruptions of the system "ocean - land/surface - atmosphere" equilibrium. Evidently these disruptions took place simultaneously with the termination of insolation change. Short-term stages and interstages, which interrupted the long-term warming and cooling during the Pleistocene, were obviously derived by the leading impact of the ocean (DUPPLESSY et al. 1981, BARASH 1988). Due to its size, the ocean is the main accumulator of the solar radiation received by the Earth, which subsequently releases to the atmosphere. Having tremendous mass and heating capacity, which significantly exceed the same parameters of the land surface, the ocean has great impact on the atmosphere towards its stability. Its impact on the atmosphere comes mainly through transit of clear heat energy and phase transformation. These processes to some extend determine the main features and the peculiarities of the atmosphere circulation and also the possibility of long term prediction of its condition (GROSSVALD \& MURATOVA 1985).

The nature of sharp coolings are not certainly determined. Evidently the main reason was the disruption of the glacial shelf in the Polar basin and Northern part of the Norwegian sea, arctic icebergs influx to the middle latitudes within the Atlantic and climate effect of the ice melting (RUDDIMAN et al. 1981). The mechanism of the glacial surging effect on climate doesn't complete with the absorption of heat due to the ice melting in the ocean; it also involves a marked expansion of relatively fresh water in the surface water layer, an increase of the winter ice cover and a sharp increase of the ocean surface albedo.

During the last years several scenarios devoted to the cooling during the Younger Dryas have appeared (BORISOVA 1990, KLIMANOV 1990). These scenarios are based on the linear interpolation between separate points in which according to the palynological analysis the climate parameters were determined. The scenario by KLIMANOV
(1990) doesn't coincide with GEOMAP simulations. He supposes that 10,500 years b. p. the maximum cooling took place within high latitudes. Whereas the reconstruction by BORISOVA (1990) correlates well with GEOMAP simulations. According to her data negative average July temperature deviations during the Younger Dryas had the trend to increase from the North to the South, it was especially marked in Western Europe. On the map of mean annual precipitation anomalies, BORISOVA has underlined the area of their sharp decreasing within North-Western and Western Europe. On the other territories mean annual precipitation was a little bit lower than the present one.

\section{Conclusions}

The climate simulation worked out for the last "nearest" to the modern time sharp short-term cooling in the Northern Hemisphere has distinctly showed that this cold phase was derived by the cooling of the North Atlantic waters. It took place probably due to the increased meridional atmospheric and ocean circulation. The distribution of negative temperature anomalies in the ocean and land surface during the Younger Dryas shows that the "epicenter" of the cooling was attached to the Eastern part of the North Atlantic between $35 \mathrm{~N}$ and $45 \mathrm{~N}$. Maximum cooling in Europe and North America was accompanied by significant decrease in precipitation and took mainly place in continental margins. On the land surface its manifestation was weaker than on the ocean. Within high latitudes the temperatures during the Younger Dryas practically didn't differ from the modern ones and were even higher than $1{ }^{\circ} \mathrm{C}$ as it is evident by pollen and fossil beetle fauna analysis. The middle part of the Younger Dryas was marked by distinct sharp cooling and aridity. This time interval was proceeded by the Bölling-Alleröd epoch of significant warming on the land surface and in the ocean according to the palaeobotanical and micropalaeontological data (MERCER 1969). During this warm epoch, the temperature of the upper layer in the Bay Biscay and adjacent parts of the Atlantic were similar to the modern ones. It means that low temperatures of the Younger Dryas were not inherited from the Glacial period but were consequences of the independent climatic process at the final stage of deglaciation. The decreasing of temperature and significant aridity caused the changes in the distribution of vegetation cover and floristic composition. Forests transformed to open woodlands. The zone of broad leaved forests almost disappeared, some of the broad leaved species were preserved in the composition of the open woodland on the spots which were favorable for their growth. The areas occupied by forest tundra, Northern taiga, forest steppe and steppe increased. To our opinion, the increase of forest tundra and Northern taiga areas was determined mainly by cooling, while increase of forest steppe and steppe areas was caused by aridity. 
The analysis of the climate and vegetation maps gives the possibility to determine the areas where landscapes have undergone great changes in comparison with the present ones. It is very important not only for the understanding of environmental dynamics but also for the prediction of its future development under climate change.

\section{References}

AVENARIUS, I. G., MURATOVA, M. V., SPASSKAYA, I. I. (1978): Paleogeography of the North Eurasia during the Late GlacialHolocene and geographical prognosis. Nauka, Moscow (in Russian), $76 \mathrm{pp}$.

BARASH, M.S. (1988): Quaternary paleooceanology of the Atlantic ocean. Nauka, Moscow (in Russian), 272 pp.

BERMAN, D. I. (1990a): Ecology of Morychus viridis (Coleoptera Byrrtidae), a mass beetle from Pleistocene deposits in the North Eastern USSR. Arctic research. Advances and prospects. - Proceedings of the conference of Arctic and Nordic countries on coordinations of research in the Arctic, Leningrad December 1988. Nauka, Moscow, 281-288 pp.

BERMAN, D. I. (1990 b): The phenomen of mass beetle genus Morychus from Pleistocene deposits in the Northeastern Asia. Current research in the Pleistocene. Vol. 7, 101-103.

BORISOVA, O. K. (1990): Climate of the Younger Dryas within nontropical area of the Northern Hemisphere. Proceeding of the Academy of Science, $n 3$, geographical seria (in Russian), $66-72$.

BUDYKO, M. I. (1986): The evolution of the biosphere. D. Reidel Publishing company, Netherlands. 423 pp.

BUTVILOVSKY, V. V., PANYCHEV, V. A., PONOMAREVA, E. A., TRESVATSKAYA, V.S. (1992): The paleogeography of Altai Mountains during the Late Glacial and Holocene. In: Glaciology of Siberia, n 4/19, Tomsk (in Russian), 18-37.

DUPPLESSY, I. C., DELIBRAIS, G. \& TURON, I. L. (1981): Deglacial warming of the Northeastern Atlantic ocean: correlation with the palaeoclimatic evolution of the European continent. Paleogeography, Paleoclimatology, Paleoecology, vol. 35, n 2/4, 121-144.

EMILIANI, C. S. (1966): Paleotemperature analysis of the Carribean cores $P-6304-8$ and $P-6304-9$ and a generalized temperature curve for the past 435,000 years. J. Geol., v. 74 , 48-64.

EMILIANI, C. S., GARTHER, S. \& LIDZ, B. (1975): Paleoclimatological analysis of Late Quaternary cores from the Northwestern Gulf of Mexico. Science, vol. 189, n 4208, 1083-1088.

EVSEEV, A. V., MURATOVA, M. V. (1986): Peculiarities of environment of the Northern Eurasia during the Younger Dryas. Proceedings of the 4th Allunion Conference on Quaternary study, Kishinev (in Russian), $76 \mathrm{p}$.

FRENZEL, B. (1968): Grundzüge der pleistozänen Vegetationsgeschichte Nord-Eurasiens, Wiesbaden, 178 pp.

GROSSVALD, M. G., MURATOVA, M. V. (1985): Climatic effect of Late-Glacial surges based on the example of the 10,500 b. p., Popular Geography and Geology, v. 9, 244-251.

IVERSEN, I. (1954): The Late Glacial flora of Denmark and its relation to climate and soil. Denmarks Geologiske Undersogelse, 2, 80, 87-119.

IVERSEN, I. (1967): Naturens udvikling siden sidste istid. Danmarks natur, Bd.1, Kobenhavn, 345.
KAPLINA, T. N., LOJKIN, A. V. (1982): Vegetation history of the coastland lowland of the Jakutia. Environment development of the USSR during the Late Pleistocene. Nauka, Moscow (in Russian), 202-207.

KARAULOVA, L.P. (1974): Palynological grounds of Pleistocene and Holocene deposits stratigraphy of the Far East. Abstract of a dissertation. Geological Institute, Moscow (in Russian), $25 \mathrm{p}$.

KHOTINSKY, N. A. (1977): Holocene of the Northern Eurasia. Nauka, Moscow (in Russian), 200 pp.

KIND, N. V. (1974): Geochronology of the Late Pleistocene based on the isotopes data. Nauka, Moscow (in Russian), $650 \mathrm{pp}$

KISELEV,S. V. (1981): Late Cenozoic beetles of the North East Siberia. Nauka, Moscow (in Russian), 116 pp.

KISELEV, S. V. (1988): Beetles fauna of Pleistocene and Holocene of the West Siberia. Modern and prehistoric fauna of the West Siberia Lowland. Nauka, Sverdlovsk (in Russian), 97-118.

KISELEV, S. V., NAZAROV, V. I. (1984): Late Pleistocene insects. Late Quaternary Environment of the Soviet Union. Univ. Minnesota Press, Minneapolis, 223-226.

KISELEV, S. V., KOLESNIKOVA, S. F., RYBAKOVA, N. O. (1987): Climate of the vegetation period during formation of the deposits of glacial complex on the Omolon river. Moscow Nature Society Bul., Dept. of Geology, vol. 62, issue 1 (in Russian), 113-119.

KLIMANOV, V.A. (1990): Quantitative characteristics of climate in the Northern Eurasia during the Late Glacial epoch. Proceedings of the Academy of Sciences, $n$ 4, geographical seria, 116-127.

KOTLYAKOV, V. M., LORIUS, K. I. (1989): Climate change during the last glacial-interglacial cycle based on the data of the glacial core. Proceedings of the Academy of Sciences, n 3, geographical seria (in Russian), 5-17.

KUTZBACH, J.E., GUETTER, P.J. (1986): The influence of changing orbital parameters and surfaceboundary conditions on climate simulations for the past 18,000 years. Journal of the Atmospheric Sciences 43, 1726-1759.

KUZMINA, S. A., KOROTYAEV, B. A. (1989): New species of the pill beetles Moruchus Ev. (Coleoptera, Byrrhidae) in the North Eastern part of the USSR. Enthomological Proceedings, vol. 66, n 2 (in Russian), 342-344.

LIBERMAN, A. A., MURATOVA, M. V., SUETOVA, I. A. (1985): The implication of nonlinear interpolation for the palaeoclimatic simulations. Methods of palaeoclimate reconstructions. Nauka, Moscow (in Russian), 48-53.

MARKOV, K. K., VELICHKO, A. A. (1967): Quaternary period (Glacial period - Anthropohenic period). Vol. 3, Nedra, Moscow (in Russian).

MERCER, J. H. (1969): The Alleröd oscillation: a Europe climatic anomaly. Arctic and Alpine Research, vol.1, n 4 , 227-234.

MILANKOVICH, M. (1938): Astronomische Mittel zur Erforschung der erdgeschichtlichen Klimate. - Handb. Geophysik., Bd. 9, 3, 134-138.

MILLER, G. H, KAUFMAN, D. S. (1991): Ice-sheet/ocean interaction at the mouth of Hudson Strait, Canada, as a trigger for Younger Dryas cooling. In: Norsk geologisk tiddskrift, vol. 71, Oslo, 149-151.

MURATOVA, M. V. (1973): Vegetation and climate history of the South-east Chukotka during the Neogen-Pleistocene. Nauka, Moscow (in Russian), 135 pp. 
MURATOVA, M. V., DENISSENKO, O. V., LUKJANOVA, T.S. (1987): The climate of the Northern Eurasia during the Younger Dryas. Vestnic MGU, Geographical seria, $n 4$ (in Russian), 69-75 pp.

MURATOVA, M. V., DENISSENKO, O. V., LUKIANOVA, T.S. (1988): Implication of nonlinear interpolation for the palaeoclimate simulation on the example of the cooling within the USSR, West Europe and Northern America at 10,500 years b. p. Vestnik MGU, Geographical Seria, n 4 (in Russian), 69-75.

MURZAEVA, V. E., KONOPLEVA, V. I., DEVYATKIN, E. V., SEREBRYANNY, L.R. (1984): Pluvial environments of the Late Pleistocene and Holocene in the arid zone of Asia and Africa. In: Proceedings of the Academy of Sciences, geographical seria, 4 (in Russian), 15-25.

NIKIPHOROVA, L.D. (1982): Dynamics of the landscapes zones during the Holocene within the North East European part of the USSR. Development of the Environment of the USSR during the Late Pleistocene. Nauka, Moscow (in Russian), 202-207.

PIAVCHENKO, N.I. (1968): Forest Steppe dynamics and forest composition in the south of Siberia during the Holocene according to the study of the bogs and sapropel deposits. Forestry Sciences, 3, 17-29.

PRENTICE, I. C., SOLOMON, A. M. (1989): Vegetation models and global change. Global Changes of the past. Ed. Bradley, R. S. Papers arising from the 1989 OIES Global Change Institute. UCAR/Office for Interdisciplinary Earth Studies, Boulder colorado, 365-383.
RUDDIMAN, W., McINTYRE, A. (1981): The North Atlantic ocean during the last deglaciation. Paleogeography, Paleoclimatology, Paleoecology, vol. 35, 2/4, 145-214.

SEREBRYANNY, L. R. (1978): The dynamics of the ice sheet and glaciaevstazy during the Late Quaternary (in Russian), Nauka, Moscow, 270 pp.

SEREBRYANNY, L.R., PSHENIN, G. N., PUNNING, J.M.K., KHALMUKHAMEDOVA, R.A. (1980): New data upon the landscape development of the Ferghana during the Late Quaternary. Humidity fluctuations in the Aral-Caspian region during the Holocene. Moscow, Nauka (in Russian), 214-222.

SOLOMON, A. M., DELCOURT, H. R., WEST, D. C., BLASING, T. J. (1980): Testing a simulation model for reconstruction of prehistoric forest-stand dynamics. Quat. Res. (N. Y.), 14, 275-293.

SUROVA, T.I., TROICKY, L. S., PUNNING, J.M.K. (1975): Palaeogeography and absolute geochronology of the Holocene in the Polar Ural. Proceedings of Estonia Academy of Sciences, chemistry-geology, vol.24, 2 (in Russian), 152-159

VELICHKO, A. A. (ed.) (1984): Late Quaternary Environments of the Soviet Union. Univ. of Minnesota Press, Minneapolis, $328 \mathrm{pp}$.

VELICHKO, A. A., FRENZEL, B., PECSI, M. (ed.) (1992): Atlas of Palaeoclimates and Palaeoenvironments of Northern Hemisphere. Geographical Research Institute HAS, Budapest, $62 \mathrm{pp}$.

VIPPER, P. V., GOLUBEVA, L. V. (1976): To vegetation history of the South West Baikal during the Holocene. Commission of the Quaternary Study Bul., 41, Nauka, Moscow (in Russian), 45-55. 